POLITYKA ENERGETYCZNA - ENERGY POLICY JOURNAL

$2020 \star$ Volume $23 \uparrow$ Issue $1 \hookleftarrow 37-48$

DOI: $10.33223 / \mathrm{epj} / 119371$

Luiza Julita OssowsKA ${ }^{1}$, Dorota Agnieszka JANISZEwsKA ${ }^{2}$

\title{
Toward sustainable energy consumption in the European Union
}

ABSTRACT: An unsustainable energy mix and energy overconsumption contribute to negative processes such as environmental pressure or energy dependency. The aim of the article is to assess the European Union countries situation in terms of sustainable energy consumption. Eurostat was were used in the analyses. The research was based on synthetic indicators for 2017 data. A non-standard method was used. In accordance with the assumptions of sustainable energy consumption, six indicators were proposed: primary energy consumption $(2005=100)$, final energy consumption $(2005=100)$, share of renewable energy in energy consumption, deficit/surplus in the 2020 renewable energy sources consumption target, energy import dependency (\%), greenhouse gas emissions intensity of energy consumption $(2000=100)$. The share of renewable energy in energy consumption and deficit/surplus in the 2020 renewable energy sources consumption target are stimulants, other features are destimulants. The European Union countries were classified into four groups due to the situation in terms of sustainable energy consumption (first class - favorable situation, second class - quite favorable situation, third class - rather unfavorable situation, fourth class - unfavorable situation). According to the results in twelve countries the situation was identified as favorable or quite favorable, while in the other sixteen countries as rather unfavorable and unfavorable. However, all

$\bowtie$ Corresponding Author: Luiza Julita Ossowska; e-mail: luiza.ossowska@tu.koszalin.pl

${ }^{1}$ Koszalin University of Technology, Poland; ORCID iD: 0000-0002-1572-8016; e-mail: luiza.ossowska@ tu.koszalin.pl

2 Koszalin University of Technology, Poland; ORCID iD: 0000-0003-1119-9388; e-mail: dorota.janiszewska@ tu.koszalin.pl

2020. The Author(s). This is an open-access article distributed under the terms of the Creative Commons Attribution-ShareAlike International License (CC BY-SA 4.0, http://creativecommons.org/licenses/by-sa/4.0/), which permits use, distribution, and reproduction in any medium, provided that the Article is properly cited. 
countries have entered the path of necessary changes. It is important to continue monitoring and analyzing the progress of European Union countries in the field of energy and climate policy.

KEYWORDS: European Union, energy policy, energy efficiency, renewable energy consumption, energy dependency

\section{Introduction}

The huge humanity demand for energy has contributed to many negative processes, such as environmental pressure or energy dependency. For the world, sustainable development is the answer to anthropogenic pressure (Giddings et al. 2002; Gericke et al. 2019; Purvis et al. 2019). Sustainable development covers all spheres of human life and activity, including the energy sector.

Sustainable development and the energy sector development are related together in the concept of sustainable energy development. The main directions of sustainable energy development include access to sufficient energy not only to the present, but also for the future generations and reduction the negative environmental impact of energy production and consumption (Lior 2008). Sustainable energy development is also associated with the need to solve the high energy dependency problem (Ozcan and Ozturk 2019). Therefore the intention of most energy-related policies is to achieve the more effective use of energy and sources and more sustainable actions for the environment (Si et al. 2018).

World organizations have begun the fight for a sustainable energy sector. The World Bank Group Energy Sector's directions for sustainable energy in the future include: achieving universal access, accelerating improvements in energy efficiency, and increasing the share of renewable energy (WB 2013). The International Energy Agency - an autonomous intergovernmental organization established in the framework of the Organization for Economic Co-operation and Development - is involved in clean energy campaigns (IEA 2019). The 2030 Agenda for Sustainable Development, adopted by all United Nations Member States in 2015, includes energy goals: SDG 7 "ensure access to affordable, reliable sustainable and modern energy for all" and SDG 13 "take urgent action to combat climate change and its impacts" (UN 2019). Actions to achieve sustainable goals require integration at different areas: sectors (including the energy sector), actors and countries (Stafford-Smith et al. 2017). Regardless of the sector, achieving sustainable development goals requires changes in consumption (Bengtsson et al. 2018) - including the energy sector and sustainable energy consumption.

The European Union has been working on its energy policy for many years. This is evidenced by numerous strategic documents and regulations. At the end of this year, the implementation time of the 2020 climate \& energy package is lapsing. The EU made a commitment to reduce greenhouse gas emissions by at least $20 \%$ below 1990 levels by 2020 , while improving energy efficiency by $20 \%$ and increasing the share of renewable energy sources to $20 \%$ (Directive 
2009/28/EC; Eurostat 2018). On February 25, 2015, the energy union strategy was published (EC 2015). The strategy aims to build an energy union that will provide consumers in the EU with secure, sustainable, competitive and affordable energy. The Energy Union consists of five related dimensions: ensuring energy security through trust and cooperation between EU countries, an integrated internal energy market, improved energy efficiency which will reduce dependence on energy imports, climate campaign and decarbonizing the economy, research and innovation supporting clean energy technologies.

Based on the European Union guidelines for necessary changes in energy consumption a sustainable energy consumption model should be associated with a reduction in energy consumption (energy efficiency increase), an increase in the share of renewable energy in energy consumption (limiting non-renewable sources), energy independence (growing importance of local resources) and reducing greenhouse gas emissions. In looking for answers to the questions whether the actions taken are sufficient and whether the European Union countries are involved to a similar degree, the aim of the article is to assess the EU countries situation in terms of sustainable energy consumption.

\section{Research method}

The research was based on synthetic indicators for 2017 data. A non-standard method was used. In accordance with the assumptions of sustainable energy consumption, six indicators were proposed: primary energy consumption $(2005=100)$, final energy consumption $(2005=100)$, share of renewable energy in energy consumption, deficit/surplus in the 2020 RES consumption target, energy import dependency (\%), greenhouse gas emissions intensity of energy consumption $(2000=100)$. The features refer to: energy efficiency, renewable energy consumption, energy dependency and greenhouse gas emissions. Eurostat data were used in the analyses.

The share of renewable energy in energy consumption and deficit/surplus in the 2020 RES consumption target are stimulants. Other features are destimulants. Diagnostic features were normalized (Wysocki and Lira 2003; Wysocki 2010):

$\uparrow$ stimulants:

$$
z_{i j}=\frac{x_{i j}-\min \left\{x_{i j}\right\}}{\max _{i}\left\{x_{i j}\right\}-\min _{i}\left\{x_{i j}\right\}}
$$

destimulants:

$$
z_{i j}=\frac{\max \left\{x_{i j}\right\}-x_{i j}}{\max _{i}\left\{x_{i j}\right\}-\min _{i}\left\{x_{i j}\right\}}
$$


where:

$$
\begin{aligned}
& i=1,2, \ldots, n, j=1,2, \ldots, m \\
& x_{i j} \quad-\text { value of the } j \text {-th feature in the statistical unit with the number } i, \\
& \min \left\{x_{i j}\right\}-\text { minimum value of } x_{i j}, \\
& \max \left\{x_{i j}\right\}-\operatorname{maximum} \text { value of } x_{i j} .
\end{aligned}
$$

In the next step synthetic indicators $\left(q_{i}\right)$ were calculated using the formula (Wojciechowski and Wojtkowski 2015; Parysek and Wojtasiewicz 1979):

$$
q_{i}=\frac{\sum_{j=1}^{m} z_{i j}}{m}
$$

where:

$$
\begin{aligned}
& i=1,2, \ldots, n, j=1,2, \ldots, m \\
& z_{i j}-\text { normalized value of } x_{i j}, \\
& m-\text { number of features. }
\end{aligned}
$$

The average $\left(q_{a}\right)$ and standard deviation $\left(s_{q}\right)$ of synthetic indicators $\left(q_{i}\right)$ were used to divide the European Union countries. Four classes were identified (Wysocki and Lira 2003):

$\rightarrow 1^{\text {st }}$ class - favorable situation $\left(q_{i}>=q_{a}+s_{q}\right)$,

$\downarrow 2^{\text {nd }}$ class - quite favorable situation $\left(q_{a}+s_{q}>q_{i}>=q_{a}\right)$,

$\checkmark 3^{\text {rd }}$ class - rather unfavorable situation $\left(q_{a}>q_{i}>=q_{a}-s_{q}\right)$,

$\checkmark 4^{\text {th }}$ class - unfavorable situation $\left(q_{i}<q_{a}-s_{q}\right)$.

\section{Results}

In 2017 (Table 1) energy efficiency measured by energy consumption indicators in the EU-28 has improved when compared to 2005, due to the primary energy consumption - over 9 p.p., while the final energy consumption - almost 6 p.p. The share of renewable sources in energy consumption reached almost $17.5 \%$, which means a deficit in relation to the 2020 indicator target set at $20 \%$. The energy dependence at the level of over $55 \%$ in comparison to previous years shows a slight upward trend. The level of greenhouse gas emissions intensity of energy consumption decreased by 13.5 p.p. compared to 2000 . Based on these indicators, synthetic indicators were calculated for each of the European Union countries. Four classes were identified according to the situation in terms of sustainable energy consumption (Table 2 and Fig. 1). 
TABLE 1. Situation in terms of sustainable energy consumption in EU in $2017-$ researched features by country

TABELA 1. Sytuacja w zakresie zrównoważonej konsumpcji energii w UE w 2017 roku badane cechy według krajów

\begin{tabular}{|c|c|c|c|c|c|c|}
\hline Specification & $\begin{array}{c}\text { Primary } \\
\text { energy } \\
\text { consumption } \\
(2005=100)\end{array}$ & $\begin{array}{l}\text { Final energy } \\
\text { consumption } \\
(2005=100)\end{array}$ & $\begin{array}{c}\text { Share of } \\
\text { energy from } \\
\text { renewable } \\
\text { sources }\end{array}$ & $\begin{array}{c}\text { Deficit/ } \\
\text { /surplus in } \\
\text { the } 2020 \text { RES } \\
\text { consumption } \\
\text { target }\end{array}$ & $\begin{array}{c}\text { Energy } \\
\text { import } \\
\text { dependency }\end{array}$ & $\begin{array}{c}\text { Greenhouse } \\
\text { gas emissions } \\
\text { intensity } \\
\text { of energy } \\
\text { consumption } \\
(2000=100)\end{array}$ \\
\hline EU-28 & 90.76 & 94.07 & 17.48 & -2.52 & 55.14 & 86.50 \\
\hline Belgium & 95.22 & 98.63 & 9.06 & -3.94 & 74.81 & 82.40 \\
\hline Bulgaria & 95.42 & 97.58 & 18.70 & 2.70 & 39.51 & 107.90 \\
\hline Czechia & 94.90 & 97.51 & 14.80 & 1.80 & 37.18 & 76.90 \\
\hline Denmark & 91.77 & 95.75 & 35.04 & 5.04 & 12.24 & 67.30 \\
\hline Germany & 92.69 & 99.50 & 15.47 & -2.53 & 63.96 & 93.60 \\
\hline Estonia & 111.78 & 99.56 & 29.13 & 4.13 & 4.10 & 101.60 \\
\hline Ireland & 96.28 & 92.64 & 10.59 & -5.41 & 67.03 & 84.70 \\
\hline Greece & 76.64 & 79.68 & 16.95 & -1.05 & 71.07 & 83.30 \\
\hline Spain & 92.11 & 86.21 & 17.56 & -2.44 & 73.83 & 84.70 \\
\hline France & 91.66 & 92.71 & 16.01 & -6.99 & 48.64 & 83.20 \\
\hline Croatia & 91.16 & 95.65 & 27.28 & 7.28 & 53.14 & 90.40 \\
\hline Italy & 82.37 & 83.94 & 18.27 & 1.27 & 76.98 & 82.40 \\
\hline Cyprus & 102.39 & 101.70 & 10.49 & -2.51 & 95.93 & 97.80 \\
\hline Latvia & 99.40 & 99.90 & 39.02 & -0.98 & 44.05 & 83.90 \\
\hline Lithuania & 76.55 & 114.48 & 26.04 & 3.04 & 75.06 & 102.50 \\
\hline Luxembourg & 89.90 & 93.30 & 6.29 & -4.71 & 95.55 & 91.60 \\
\hline Hungary & 92.97 & 98.82 & 13.52 & 0.52 & 62.54 & 79.80 \\
\hline Malta & 88.13 & 134.01 & 7.27 & -2.73 & 103.30 & 62.90 \\
\hline Netherlands & 92.83 & 93.03 & 6.46 & -7.54 & 51.97 & 95.20 \\
\hline Austria & 100.29 & 102.66 & 33.14 & -0.86 & 63.94 & 85.30 \\
\hline Poland & 112.74 & 121.34 & 10.96 & -4.04 & 38.30 & 90.10 \\
\hline Portugal & 91.83 & 87.16 & 30.61 & -0.39 & 77.93 & 86.80 \\
\hline Romania & 89.89 & 94.33 & 24.45 & 0.45 & 23.12 & 83.10 \\
\hline Slovenia & 95.93 & 101.08 & 21.06 & -3.94 & 51.02 & 86.20 \\
\hline Slovakia & 92.74 & 96.27 & 11.47 & -2.54 & 64.85 & 83.00 \\
\hline Finland & 95.61 & 100.19 & 40.92 & 2.92 & 44.18 & 73.20 \\
\hline Sweden & 94.28 & 96.42 & 54.20 & 5.20 & 26.76 & 70.50 \\
\hline United Kingdom & 79.14 & 87.35 & 9.73 & -5.27 & 35.59 & 84.40 \\
\hline
\end{tabular}

Source: own study based on: Eurostat Database. 
TABLE 2. Situation in terms of sustainable energy consumption in EU in 2017 researched features by classes

TABELA 2. Sytuacja w zakresie zrównoważonej konsumpcji energii w UE w 2017 roku badane cechy według klas

\begin{tabular}{|l|r|r|r|r|c|}
\hline \multicolumn{1}{|c|}{ Specification } & \multicolumn{1}{c|}{$1^{\text {st }}$ class } & $2^{\text {nd }}$ class & $3^{\text {rd }}$ class & $4^{\text {th }}$ class & EU-28 \\
\hline Primary energy consumption $(2005=100)$ & 93.89 & 90.79 & 92.90 & 97.20 & 90.76 \\
\hline Final energy consumption (2005=100) & 97.45 & 91.68 & 98.23 & 108.68 & 94.07 \\
\hline Share of energy from renewable sources & 43.39 & 23.36 & 17.51 & 8.29 & 17.48 \\
\hline Deficit/surplus in the 2020 RES consumption target & 4.39 & 0.80 & -2.03 & -4.31 & -2.52 \\
\hline Energy import dependency & 27.73 & 47.02 & 62.29 & 77.01 & 55.14 \\
\hline $\begin{array}{l}\text { Greenhouse gas emissions intensity of energy consumption } \\
(2000=100)\end{array}$ & 70.33 & 85.87 & 88.48 & 87.52 & 86.50 \\
\hline
\end{tabular}

Source: own study based on: Eurostat Database.

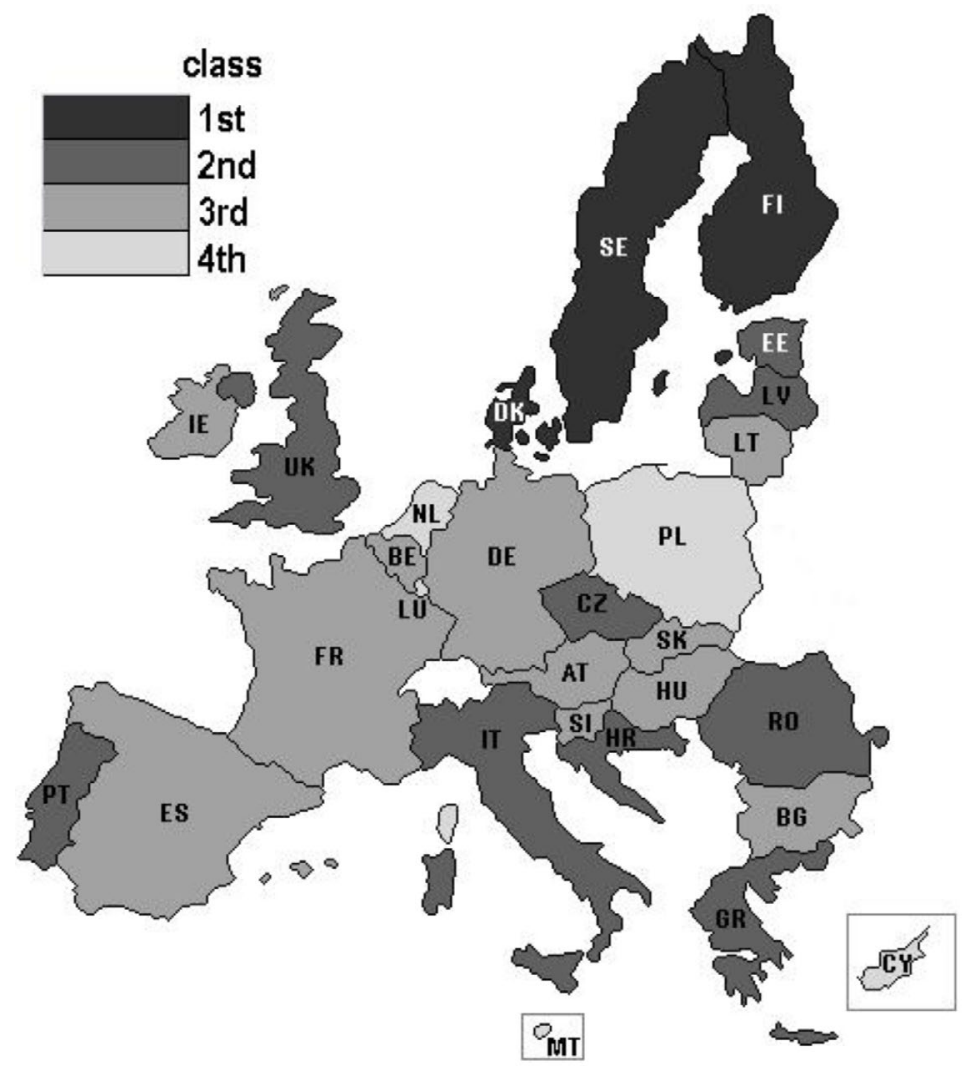

Fig. 1. Situation in terms of sustainable energy consumption in the EU in 2017 - researched classes by country Source: own study based on: Eurostat Database

Rys. 1. Sytuacja w zakresie zrównoważonej konsumpcji energii w UE w 2017 roku - badane klasy według krajów 
The first class covers Denmark, Finland and Sweden. Three countries of Northern Europe are characterized by a favorable situation in terms of sustainable energy consumption. Scandinavian countries are distinguished by the most favorable indicators values in the renewable energy consumption. In these countries, the share of renewable sources in energy consumption exceeds $43 \%$ on average (Denmark $-35 \%$, Finland $-41 \%$, Sweden $-51 \%$ ). The Nordic countries have natural conditions for renewable energy production - coastal areas allow for wind energy use, and mountainous areas (in Sweden and Finland) for the use of hydropower. In addition, agricultural and forestry biomass is used. The fairly widespread use of renewable energy results in these countries have already exceeding the 2020 targets (Denmark and Sweden over 5\%, Finland almost 3\%). The situation of these countries in terms of energy dependence is quite favorable mainly due to Denmark and Sweden, which are among the most energy independent countries. Greenhouse gas emissions intensity of energy consumption by the $1^{\text {st }}$ class countries has been significantly reduced compared to 2000 - almost 30 p.p. on average (only Malta achieved a better result). The energy efficiency of Scandinavian countries is below average (the $2^{\text {nd }}$ class countries achieved better results, while the $3^{\text {rd }}$ class countries achieved a similar result). However, the geographical and climatic conditions of Northern European countries contribute to greater energy needs (shorter days, cooler months).

The second class consists of nine countries (Czechia, Estonia, Greece, Croatia, Italy, Latvia, Portugal, Romania and the United Kingdom). These countries represent quite a favorable situation in terms of sustainable energy consumption. Generally, this group has the best energy efficiency situation. In the $2^{\text {nd }}$ class countries the level of primary energy consumption decreased over 9 p.p., and final energy consumption over 8 p.p. compared to 2005. However, the situation of individual countries is quite diverse. Czechia, Estonia and Latvia are characterized by higher values of these indicators (in Estonia the level of primary energy consumption exceeded the value from 2005). The Southern European countries are in a better position due to climatic and geographical conditions - contrary to Northern Europe, there are fewer cold days requiring additional heating and more daylight, not requiring artificial lighting. In the $2^{\text {nd }}$ group the share of renewable sources in energy consumption reached $23 \%$ - more than in the EU-28. The lowest value are characteristic of: the United Kingdom (below 10\%), Czechia, Greece and Italy - several percent each, and the remaining countries - over $20 \%$ (Latvia $30 \%$ ). The diversity is due to, among others, national energy sources. The richness of local sources contributes to energy independence. The $2^{\text {nd }}$ class dependence reached $47 \%$, therefore, this group includes the most energy independent country - Estonia. The country's energy mix is based on renewable energy sources and oil sands - both sources are national. However, high $\mathrm{CO}_{2}$ emissions are associated with the use of oil sands, which has increased in Estonia's energy sector compared to 2000. This level decreased in other $2^{\text {nd }}$ class countries.

The third class includes eleven countries (Belgium, Bulgaria, Germany, Ireland, Spain, France, Lithuania, Hungary, Austria, Slovenia and Slovakia). These countries are characterized by a rather unfavorable situation in terms of sustainable energy consumption. This is the largest and most diverse group. Energy efficiency indicators exceeded the EU-28 level. Austria, exceeded the 2005 level for both primary and final energy consumption (hence despite the large share of 
renewable energy in the energy mix, the country's position is in the $3^{\text {rd }}$ class). Moreover, in terms of final energy consumption, Lithuania and Slovenia exceeded 100. The 3rd class renewable energy indicators reflect the level of the EU-28. A majority of the 3rd group countries have not yet achieved the 2020 target (except Bulgaria, Lithuania and Hungary). The analyzed countries are quite energy dependent. The indicator does not exceed 50\%. only in Bulgaria and France. This is associated with the use of coal in Bulgaria and nuclear energy in France. However, these sources are not sustainable. In the $3^{\text {rd }}$ class countries, greenhouse gas emissions intensity of energy consumption decreased compared to 2000, while in Bulgaria and Lithuania the indicator exceeded 100 , in other countries it exceeds $80 \%$.

The fourth class includes five countries (Netherlands, Malta, Luxembourg, Cyprus and Poland). These countries are characterized by an unfavorable situation in terms of sustainable energy consumption. The indicators of energy efficiency, renewable energy consumption and energy dependence are the least favorable in this group - according to the other groups. Generally, compared to 2005, primary energy consumption decreased only slightly (and even increased in Poland and Cyprus). Final energy consumption increased (consumption decreased only in the Benelux countries) - this is the only growth group among the EU-28 countries. The fourth group countries are characterized by the lowest share of renewable sources in energy consumption next to Belgium, United Kingdom and Ireland - not exceeding $11 \%$. The $4^{\text {th }}$ class countries did not reach the 2020 target. Luxembourg, Cyprus and Malta are the most energy dependent countries of the European Union - due to the dominance of oil in energy consumption, as well as the lack of own resources. These are very small, specific countries - Cyprus and Malta are islands. Poland is in a better situation, which results from its own hard and brown coal sources. However, coal energy consumption is associated with significant $\mathrm{CO}_{2}$ emissions. In the $4^{\text {th }}$ class countries, the greenhouse gas emissions intensity of energy consumption compared to 2000 is slightly lower than in the $3^{\text {rd }}$ class, mainly due to Malta, which achieved the best result among all EU countries. However, until recently Malta has almost entirely based its energy sector on crude oil. Currently, Malta's energy mix also includes natural gas and, to a small extent, renewable energy sources. In the other $4^{\text {th }}$ class countries, the greenhouse gas emissions intensity of energy consumption exceeded $90 \%$ compared to 2000 .

\section{Discussion}

According to the World Bank Group's Energy efforts to improve energy efficiency are one of the most cost-effective ways to expand supply and reduce the energy environmental impact (WB 2013). Moreover, energy transition - from fossil fuels to renewable energy sources - is necessary for many reasons. Two of them are particularly important. Firstly-increased renewable energy intensity leads to a decline in greenhouse gas emissions (Dong et al. 2018). Secondly - replacing fossil fuels by renewable energy sources reduces countries' demand for energy imports and their 
dependence on exporting countries (Gökgöz and Güvercin 2018). Therefore, the environment is not the only one that needs the energy transition from non-renewable to renewable sources. Other events contribute to this process: concerns over energy security especially high and volatile crude oil prices and high dependency on foreign energy supply (Ozcan and Ozturk 2019).

The increase in the share of renewable energy in energy consumption causes the decrease of the non-renewable energy consumption. This transition is associated with long-term changes particularly difficult for member states that base their energy mix on non-renewable sources (Ossowska 2019).

Due to greenhouse gas emissions nuclear energy is a special case. This type of energy does not contribute to $\mathrm{CO}_{2}$ emissions (Lee et al. 2017), but it this not sustainable energy due to the Three Mile Island, Chernobyl or Fukushima accidents (Friedman 2011). The case of France shows how difficult it is to give up this type of energy for renewable energy. The coal-rich countries are a similar problem, especially in Central and Eastern Europe, these countries rely on their own energy resources. This is related to the use of local resources and energy independence (Ringel and Knodt 2018). Access to energy sources is the basis for the functioning of the economy. If the economy meets the energy needs based on its own resources, it is not dependent on the other countries (Janiszewska 2019).

It is hard to reach all sustainable energy goals simultaneously and it is difficult to define what to achieve in first order. The goals are interrelated. The acceleration of $\mathrm{CO}_{2}$ reduction can be one of the main driving forces for renewable policy not only at European Union level by also at global level (Blazquez et al. 2018).

The European Union is aware of major challenges from the increased threats of climate change, with serious consequences in the energy sector. The European Union countries continue changes by establishing the next stages of policies on climate and energy. The European Union set a $\mathrm{CO}_{2}$ reduction target of at least $40 \%$ below 1990 levels by 2030 and targets of at least $27 \%$ for renewable energy and energy efficiency by 2030. The next step includes the long-term 2050 target (EC 2016; EP 2019). It is very important to continue energy policy actions. A long-term, stable energy policy and regulations guarantee the development of the energy sector in a given direction (Paska and Surma 2013).

\section{Conclusions}

According to the aim of the article the situation of the EU countries in terms of sustainable energy consumption was assessed. In 12 countries the situation was identified as favorable or quite favorable, while in other 16 countries as rather unfavorable and unfavorable. However, all countries have entered the path of necessary changes.

According to energy resources versus exploitation and greenhouse gas versus emissions, the increase of the share of renewable sources in energy consumption is a necessary but insufficient 
action. A complex approach to the energy sector is needed, taking the optimization of energy consumption, replacing fossil and other non-renewable fuels with renewable sources into account. Together, these activities contribute to reducing $\mathrm{CO}_{2}$ emissions.

Striving for sustainable energy consumption is a long and difficult process. Energy demand in the European Union countries is diverse. Due to the specific geographical and climatic conditions - quite larger in Northern Europe and quite smaller in Southern Europe. The importance of renewable energy sources in the energy mix also varies from country to country. The main reasons are national capabilities and resources. It is more difficult to make changes in countries with non-renewable energy sources, especially if they have limited possibilities in renewable sources. Countries using their own sources (even non-renewable) are characterized by a lesser dependence on energy. In addition, the consequences of Brexit are still difficult to define for the European Union. All these problems mean that the European Union countries still have a long way to go in sustainable energy consumption, but the positive fact is that the change has already begun. It is important to continue monitoring and analyzing the progress of European Union countries in the field of energy and climate policy.

\section{References}

Bengtsson et al. 2018 - Bengtsson, M., Alfredsson, E., Cohen, M., Lorek, S. and Schroeder, P. 2018. Transforming systems of consumption and production for achieving the sustainable development goals: moving beyond efficiency. Sustainability Science 13, pp. 1533-1547.

Blazquez et al. 2018 - Blazquez, J., Nezamuddin, N. and Zamrik, T. 2018. Economic policy instruments and market uncertainty: Exploring the impact on renewables adoption. Renewable and Sustainable Energy Reviews 94, pp. 224-233.

Directive 2009/28/EC of the European Parliament and of the Council of 23 April 2009 on the promotion of the use of energy from renewable sources and amending and subsequently repealing Directives 2001/77/EC and 2003/30/EC. [Online] https://eur-lex.europa.eu/legal-content/EN/TXT/PDF/?uri=CELEX:32009L0028\&from=EN [Accessed: 2020-02-25].

Dong et al. 2018 - Dong, K., Hochman, G., Zhang, Y., Sun, R., Li, H. and LiaO, H. 2018. CO 2 emissions, economic and population growth, and renewable energy: Empirical evidence across regions. Energy Economics 75, pp. 180-192.

EC 2016. Energy Next steps for a sustainable European future. Communication from the Commission to the European Parliament, the Council, the European Economic and Social Committee, the Committee of the Regions (COM/2016/739).

EC 2015. Energy Union Package. Communication from the Commission to the European Parliament, the Council, the European Economic and Social Committee, the Committee of the Regions and the European Investment Bank (COM/2015/080).

EP 2019. European policies on climate and energy towards 2020, 2030 and 2050. European Parliament: Policy Department for Economic, Scientific and Quality of Life Policies (PE 631.047).

Eurostat 2018. Sustainable development in the European Union, Luxembourg, p. 133.

Eurostat Database. [Online] http://ec.europa.eu/eurostat/data/database [Accessed: 2020-02-25].

Friedman, Sh.M. 2011. Three Mile Island, Chernobyl, and Fukushima: An analysis of traditional and new media coverage of nuclear accidents and radiation. Bulletin of the Atomic Scientists 67, pp. 55-65. 
Gericke et al. 2019 - Gericke, N., Boeve-de Pauw, J., Berglund, T. and Olsson, D. 2019. The Sustainability Consciousness Questionnaire: The theoretical development and empirical validation of an evaluation instrument for stakeholders working with sustainable development. Sustainable Development 27 , pp. 35-49.

Giddings et al. 2002 - Giddings, B., Hopwood, B. and O’Brien, G. 2002. Environment, economy and society: Fitting them together into sustainable development. Sustainable Development 10, pp. $187-196$.

GöKGÖz, F. and GÜVERCIN, M.T. 2018. Energy security and renewable energy efficiency in EU. Renewable and Sustainable Energy Reviews 96, pp. 226-239.

IEA 2019. [Online] https://www.iea.org/ [Accessed: 2020-02-25].

JANISZEWSKA, D. 2019. Diversification of energy production and consumption in European Union countries. Energy Policy Journal 2 (22), pp. 5-19.

LeE et al. 2017 - LeE, S., KIM, M. and LeE, J. 2017. Analyzing the impact of nuclear power on $\mathrm{CO}_{2}$ emissions. Sustainability 9, pp. 1428-1440.

Lior, N. 2008. Energy resources and use: The present situation and possible paths to the future. Energy 33, pp. $842-857$.

Ossowska, L. 2019. Consequences of the energy policy in member states of the European Union. Energy Policy Journal 2 (22), pp. 21-32.

Ozcan, B. and Ozturk, I. 2019. Renewable energy consumption-economic growth nexus in emerging countries: A bootstrap panel causality test. Renewable and Sustainable Energy Reviews 104, pp. 30-37.

PARYSEK, J. and WoJTASIEwicz, L. 1979. Methods of regional analysis and methods of regional planning (Metody analizy regionalnej i metody planowania regionalnego). Warszawa: Polish Scientific Publishers PWN, p. 25-26 (in Polish).

PASka, J. and Surma, T. 2013. The energy policy of Poland against the background of the European Union's energy policy (Polityka energetyczna Polski na tle polityki energetycznej Unii Europejskiej). Polityka Energetyczna - Energy Policy Journal Vol. 16, Iss. 4, pp. 7-19 (in Polish).

Purvis et al. 2019 - Purvis, B., MaO, Y. and Robinson, D. 2019. Three pillars of sustainability: in search of conceptual origins. Sustainability Science 14, pp. 681-695.

Ringel, M. and KNODT, M. 2018. The governance of the European Energy Union: efficiency, effectiveness and acceptance of the Winter Package 2016. Energy Policy 112, pp. 209-220.

Si et al. 2018 - Si, S., Lyu, M., Lin LAwell, C-Y.C. and Chen, S. 2018. The effects of energy-related policies on energy consumption in China. Energy Economics 76, pp. 202-227.

Stafford-Smith et al. 2017 - Stafford-Smith, M., Griggs, D., Gaffney, O., Ullah, F., Reyers, B., Kanie, N., Stigson B., Shrivastava, P., Leach, M. and O'Connell, D. 2017. Integration: the key to implementing the Sustainable Development Goals. Sustainability Science 12, pp. 911-919.

UN 2019. Sustainable Development Goals. [Online] https://www.un.org/sustainabledevelopment/energy/ [Accessed: 2020-02-25].

Wojciechowski, S. and Wojtкowski, D. 2015. Methodology and research results (Metodologia i wyniki badań). [In:] Woźniak, K. ed. Analytical tools in economic sciences (Narzędzia analityczne w naukach ekonomicznych). Kraków: Mfiles, p. 111 (in Polish).

WB 2013. Toward a Sustainable Energy Future for All: Directions for the World Bank Group's Energy Sector. Washington. [Online] http://documents.worldbank.org/curated/en/745601468160524040/Toward-a-sustainable-energy-future-for-all-directions-for-the-World-Bank-Group-8217-s-energy-sector [Accessed: 2020-02-25].

WysOcki, F. 2010. Taxonomic methods in recognizing economic types of rural agriculture (Metody taksonomiczne w rozpoznawaniu typów ekonomicznych rolnictwa obszarów wiejskich). Poznań: Uniwersytet Przyrodniczy w Poznaniu, pp. 151-152 (in Polish). 
Wysocki, F. and LiRA, J. 2003. Descriptive statistics (Statystyka opisowa). Poznań: AR Publishing House in Poznań, pp. 173-175 (in Polish).

\section{W kierunku zrównoważonej konsumpcji energii w Unii Europejskiej}

\section{Streszczenie}

Niezrównoważony mix energetyczny i nadmierna konsumpcja energii prowadzą do negatywnych procesów, takich jak presja środowiskowa czy zależność energetyczna. W związku z tym celem artykułu jest ocena sytuacji krajów Unii Europejskiej w zakresie zrównoważonej konsumpcji energii. Dane pochodzą z Eurostatu. Zakres czasowy obejmuje 2017 rok. Analizę przeprowadzono w oparciu o mierniki syntetyczne. Zastosowano metodą bezwzorcową. Nawiązując do zrównoważonej konsumpcji energii uwzględniono sześć wskaźników: konsumpcję energii pierwotnej (2005=100), konsumpcję energii finalnej $(2005=100)$, udział źródeł odnawialnych w konsumpcji energii, niedobór/nadwyżka realizacji celu w zakresie udziału odnawialnych źródeł w konsumpcji energii do 2020 roku, zależność energetyczna (\%), intensywność emisji gazów cieplarnianych w zużyciu energii $(2000=100)$. Udział źródeł odnawialnych w konsumpcji energii oraz niedobór/nadwyżka realizacji celu 2020 są stymulantami, pozostałe cechy to destymulanty. Kraje Unii Europejskiej podzielono na cztery zróżnicowane grupy z uwagi na sytuację w zakresie zrównoważonej konsumpcji energii (klasa pierwsza - sytuacja korzystna, klasa druga - sytuacja dość korzystna, klasa trzecia - sytuacja raczej niekorzystna, klasa czwarta - sytuacja niekorzystna). Zgodnie z wynikami w dwunastu krajach sytuację określono jako korzystną lub dość korzystną, natomiast w kolejnych szesnaście jako niekorzystną lub raczej niekorzystną. Jednak wszystkie kraje wkroczyły na drogę niezbędnych zmian. Ważne jest dalsze monitorowanie i analizowanie postępów krajów Unii Europejskiej w zakresie polityki energetycznej i klimatycznej.

SŁowA KLUCZOWE: efektywność energetyczna, Unia Europejska, polityka energetyczna, konsumpcja energii odnawialnej, zależność energetyczna 